\title{
HERBICIDE EFFECTS ON PLANT DISEASE
}

\author{
Stephen O. Duke, ${ }^{1}$ Antonio L. Cerdeira ${ }^{2}$ and Marcus B. Matallo ${ }^{3}$
}

${ }^{1}$ Natural Products Utilization Research Unit, Agricultural Research Service, United States Department of Agriculture, P. O. Box 8048, University, MS 38677, USA

${ }^{2}$ Brazilian Department of Agriculture, Agricultural Research Service, EMBRAPA/Environment, C.P. 69, Jaguariuna-SP-13820-000, Brazil

${ }^{3}$ Weed Science Lab., Instituto Biologico C.P. 70, Campinas, SP, 13001-970, Brazil.

\section{INTRODUCTION}

To be effective, herbicides they must have strong biological activity against plants. Indirectly through their effects on plants, herbicides can influence almost any process or interaction of the plant, including its susceptibility to plant diseases. In some cases, herbicides also have direct effects on plant pathogens. In this short review, we will discuss both types of effect, and, where possible, provide the mechanism for the effect. We provide a separate section for glyphosate because of the relatively large amount of information on the effects of this very important herbicide on plant diseases and the fact that there have been many seemingly conflicting claims of the effect of glyphosate on diseases in glyphosate-resistant crops (Duke \& Cerdeira, 2005).

The topic of herbicide effects on plant diseases has been reviewed previously, either as a single topic (e.g., Altman, 1991; Altman \& Campbell, 1979; Katan \& Eshel, 1973; Levesque et al., 1992) or as part of a more extensive review on secondary effects of pesticides (several of these are in the book by Altman, 1993) or chemical effects on microbial weed biocontrol agents (Hoagland, 1996). There have been no recent reviews of this topic, but a large amount of information has not been generated since the last review of this topic, except in the case of glyphosate.

\section{EFFECTS WITH UNKNOWN MECHANISMS}

Most of the reported effects of herbicides on plant diseases have been from field studies that do not allow determination of whether the observed effect is due to a direct herbicide-pathogen interaction or to an indirect effect of making the plant less or more resistant to the pathogen. In some cases, such as the decrease of vascular wilt disease due to Fusarium oxysporum in melon caused by acetochlor treatment, direct fungitoxic effects were eliminated as contributing to the effect of the herbicide, but the mechanism was not determined (Cohen et al., 1996). More commonly, studies provide no clue as to the mechanism of the effect. For example, Sharma and Sohi (1983) showed that bromacil, diuron, nitrofen, and alachlor all reduced disease severity of Phaseolus vulgaris by Rhizoctonia solani, but there were no data to suggest a mechanism.

There are other studies showing enhancement of plant diseases by herbicides. In a survey of the effects of twelve herbicides (bentazon, acifluorfen, chlorimuron, fluazifop, diclofop, sethoxydim, imazaquin, metribuzin, oryzalin, thidiazuron, diaminozide, and mefluidide) on disease severity of four plant pathogens (Alternaria cassiae, Colletotrichum coccodes, C. truncatum, and Fusarium lateritium), all of the herbicides enhanced disease severity of at least one of the pathogens to a host plant (Caulder et al., 1987). The mechanisms of these effects were not explored. There has been no organized effort to analyze the data that exists to understand the conditions, the herbicides and their doses, the species of plants, and the species of pathogens involved in herbicide-plant disease interactions in order to produce principles or generalizations that might be used to predict these interactions. Understanding the mechanisms of the interactions should aid in such an effort.

\section{DIRECT EFFECTS}

Unfortunately, there are few data available on the direct effects of herbicides on plant pathogens. However, some herbicides are directly toxic to plant pathogens at rates that are applied to crops. Table 1 lists some of the herbicides that have this property. In a less definitive study, Ahmad and Malloch (1995) found $1 \mathrm{mM}$ glufosinate to reduce agricultural soil bacteria populations by $40 \% 14$ days after soil treatment.

Table 1. Direct inhibitory effects of herbicides on plant pathogens.

\begin{tabular}{lll}
\hline Herbicide & Pathogen & Reference \\
\hline Bentazon & Colletotrichum truncatum & Caulder et al., 1987 \\
Bromoxynil & $\begin{array}{l}\text { Rhizoctonia cerealis } \\
\text { Pseudocercosporella herpotrichoides }\end{array}$ & Kataria \& Gisi, 1990 \\
Diclofop-methyl & Colletotrichum truncatum & Caulder et al., 1987 \\
\hline
\end{tabular}




\begin{tabular}{|c|c|c|}
\hline Dinoseb & $\begin{array}{l}\text { Aspergillis niger } \\
\text { Alternaria tenuia }\end{array}$ & Kovacs \& Malligni, 1975 \\
\hline \multirow[t]{2}{*}{ Glufosinate } & Aspergillis flavus & Tubajika \& Damann, 2002 \\
\hline & Verticilium alboatrum & Ahmad \& Malloch, 1995 \\
\hline \multirow[t]{3}{*}{ Glyphosate } & Puccinia lagenophora & $\begin{array}{l}\text { Wyse \& Muller-Scharer, } 2001 \text { Dreschlera teres } \\
\text { Toubia-Rhame et al., } 1995\end{array}$ \\
\hline & Calonectria crotalariae & Berner et al., 1991 \\
\hline & $\begin{array}{l}\text { Pythium ultimum } \\
\text { Fusarium solani }\end{array}$ & Kawate et al., 1992 \\
\hline Paraquat & Dreschlera teres & Toubia-Rhame et al., 1995 \\
\hline Trifluralin & Fusarium solani & Yu et al., 1988 \\
\hline
\end{tabular}

As far as we know, the effects of glufosinate on plant disease are due to direct fungitoxic effects. It is a non-selective herbicide, so its effects are best seen in glufosinate-resistant crops. Glufosinate has antimicrobial activity in glufosinate-resistant soybeans (Pline et al., 2001), rice (Uchimiya et al., 1993), and creeping bentgrass (Liu et al., 1998: Wang et al., 2003), protecting these crops from bacterial and fungal diseases.

Metabolic transformation by the plant of the herbicide to a more fungitoxic compound is possible. We are unaware of any examples of this, and we have not found studies looking for such a phenomenon. Such a mechanism might be more probable with herbicides for which crops are naturally resistant due to rapid metabolic degradation of the herbicide.

It is not unusual for low rates of herbicides to stimulate in vitro pathogen growth (e.g., Yu et al., 1988). Hormesis (the stimulatory effect of a subtoxic level of a toxin) is common with both fungicide effects on fungi and herbicide effects on plants (Duke et al., 2006). Thus, dose rates are likely to be highly important in both direct and indirect effects of herbicides on plant disease.

\section{INDIRECT EFFECTS}

Subtoxic levels of herbicides can increase or decrease resistance to plant diseases via indirect effects on the crop. For example, inhibitors of protoporphyrinogen oxidase cause enough oxidative stress at sublethal levels to induce production of phytotalexins (Kömives \& Casida, 1983). High levels of glyceollin are induced by lactofen in soybeans, resulting in protection from white mold (Sclerotinia stem rot) (Dann et al., 1999). The use label for lactofen in the USA indicates that it can be used for white mold management in soybeans. The information on effects of this class of herbicides on plant disease resistance mechanisms suggests that an unintended effect of sublethal doses of this class of herbicides to off target vegetation or to crop and weed species that are naturally resistant is induction of resistance to plant pathogens.

Herbicides with different mechanisms of action can also stimulate production of phytoalexins and thereby influence plant disease resistance. For example, pretilachlor and butachlor trigger accumulation of the phytoalexins momilactone A and sakurantetin in rice leaves (Tamogami et al., 1995). A study by Grinstein et al. (1984) found that trifluralin potentiated cotton and tomato to produce fungitoxic compounds when treated with vascular wilt-causing fungi. A later study showed that a related herbicide, pendimethalin, induces the synthesis of the phytoalexin tomatine in tomato (El-Shanshoury et al., 1995).

Another potential indirect effect is alternation of plant metabolism or physiology in a way that makes it more susceptible or resistant to plant pathogens. For example, induction of higher levels of root exudate (e.g., Liu et al., 1997) or altered mineral nutrition (proposed by Neumann et al., 2006).

\section{THE SPECIAL CASE OF GLYPHOSATE}

Glyphosate is the most widely used herbicide worldwide. Its mode of action is inhibition of the shikimic acid pathway which produces aromatic amino acids, as well as secondary plant products involved in resistance of plants to plant pathogens (Duke et al., 2003). Soon after the mode of action of this herbicide was discovered, several laboratories showed that sub-lethal treatments of glyphosate caused lowered phytoalexin levels and increased susceptibility to plant pathogens (Table 2).

Table 2. Correlation of effects of glyphosate on reduced phenolic compound levels and increased susceptibility to a plant pathogen.

\begin{tabular}{|c|c|c|c|}
\hline Plant & $\begin{array}{l}\text { Phenolic } \\
\text { compound(s) }\end{array}$ & Pathogen & Reference \\
\hline Cassia obtusifolia & chromenes & Alternaria cassiae & Sharon et al., 1992 \\
\hline Glycine max & glyceollin & $\begin{array}{l}\text { Phytophthora megasperma } \\
\text { Pseudomonas syringae }\end{array}$ & $\begin{array}{l}\text { Ward, } 1984 \\
\text { Holliday \& Keen, } 1982\end{array}$ \\
\hline Medicago sativa & medicarpin & Verticillium albo atrum & Latunde-Dada \& Lucas, 1985 \\
\hline
\end{tabular}


However, effects on phytoalexin synthesis may only be part of the cause for increased virulence of plant pathogens to glyphosate-treated plants. Liu et al. (1997) found reduced lignification and alterations in root exudates caused by glyphosate also contributed to susceptibility to Pythium spp. Neumann et al. (2006) proposed that glyphosate could reduce resistance to pathogens by limiting micronutrient availability.

Glyphosate is so effective at lowering resistance to plant diseases that it was tested extensively as a synegergist for microbial weed biocontrol products (Caulder et al., 1987; Christy et al., 1993). The sulfonium salt of glyphosate synergized the efficacy of an undefined bacterial plant pathogen, but the consistency of the effect in the field was not good.

Theoretically, there should be no phytoalexin-mediated effect of glyphosate on disease resistance in glyphosate-resistant crops, as the shikimic pathway is not blocked by the herbicide in these transgenic crops. Moreover, the sometimes fungicidal activity of glyphosate (Table 1) might prove beneficial to glyphosate-resistant crops. However, reports of both enhanced and reduced disease severity have been reported in glyphosate-resistant crops (Duke \& Cerdeira, 2005). Recently, glyphosate was reported to have both preventative and curative properties on rust diseases in both glyphosate-resistant wheat and -soybean (Anderson and Kolmer, 2005; Feng et al., 2005). In other cases, no effect of glyphosate on disease in glyphosate-resistant crops was found: e.g., Fusarium solani in soybean (Sanogo et al., 2001).

\section{CONCLUSIONS}

Herbicides have the potential to affect plant disease by several mechanisms. These secondary effects of herbicides have not been sufficiently studied to fully understand their environmental toxicology implications or for an adequate knowledge of them to enhance integrated pest management. This information is especially important in the context of biocontrol of weeds with plant pathogens (Christy et al., 1993).

\section{REFERENCES}

AHMAD, I. AND D. MALLOCH. 1995. Interaction of soil microflora with the bioherbicide phosphinothricin. Agric. Ecosystems Environ. 54: 165-174.

ALTMAN, J. 1991. Herbicide -pathogen interaction in plant disease. Pesticide Outlook 2(1); 17-21.

ALTMAN, J. (Ed.) 1993. Pesticide Interactions in Crop Production: Beneficial and Deleterious Effects. CRC Press, Boca Raton, FL, 579 pp.

ALTMAN, J. AND C.L. CAMPBELL. 1979. Herbicides and environment: a review on stimulating and inhibiting interactions with plant diseases. Z. Pflanzenkrankheiten Pflanzenschutz 86: 290-302.

ANDERSON, J.A. AND J.A. KOLMER. 2005. Rust control in glyphosate tolerant wheat following application of the herbicide glyphosate. Plant Dis. 89: 1136-1142.

BERNER, D.K., G.T. BERGGREN, AND J.P. SNOW. 1991. Effects of glyphosate on Calonectria crotalariae and red crown rot of soybean. Plant Dis. 75: 809-813.

CAULDER, J.D., A.R. GOTLEIB, L.STOWELL, AND A.K. WATSON. 1987. Herbicidal compositions comprising microbial herbicides and chemical herbicides or plant growth regulators. Eur. Pat. Appl. CODEN: EPXXDW EP 207653 A1 19870107 CAN 106:80406 AN 1987:80406 39 pp.

CHRISTY, A.L., K.A. HERBST, S.J. KOSTKA, J.P. MULLEN, AND P.S. CARLSON. 1993. Synergizing weed biocontrol agents with chemical herbicides. Amer. Chem. Soc. Symp. Ser. 524: 87-100.

COHEN, R., B. BLAIER, A.A. SCHAFFER, AND J. KATAN. 1996. Effect of acetochlor treatment on Fusarium wilt and sugar content in melon seedlings. Eur. J. Plant Pathol. 102: 45-50.

DANN, E.K., B.W. DIERS, AND R. HAMMERSCHMIDT. 1999. Suppression of Sclerotinia stem rot of soybean by lactofen herbicide treatment. Phytopathology 89: 598-602.

DUKE, S.O., N. CEDERGREEN, E.D. VELINI, AND R.G. BELZ. 2006. Hormesis: Is it an important factor in herbicide use and allelopathy. Outlooks on Pest Management 17: 29-33. 
DUKE, S. O., S. R. BAERSON, and A.M. RIMANDO. 2003. Herbicides: Glyphosate. In Encyclopedia of Agrochemicals, J.R. Plimmer, D.W. Gammon, and N.N. Ragsdale, eds., John Wiley \& Sons, New York. http://www.mrw.interscience.wiley.com/eoa/articles/agr119/frame.html

DUKE, S.O. and A.L. CERDEIRA. 2005. Potential environmental impacts of herbicide-resistant crops. In Collection of Biosafety Reviews, Vol. 2, International Centre for Genetic Engineering and Biotechnology, Trieste, Italy, pp. 66-143. Available at: http://www.icgeb.org/ bsafesrv/resources/dukecerdeira.pdf

FENG, P.C.C., G.J. BALEY, W.P. CLINTON, G.J. BUNKERS, M.F. ALIBHAI, T.C. PAULITZ, and K.K. KIDWELL. 2005. Glyphosate inhibits rust diseases in glyphosate-resistant wheat and soybean. Proc. Natl. Acad. Sci. USA 102: 17290-17295.

EL-SHANSHOURY, A., R. EL-RAHEEM, S.M. ABU EL-SOUOUD, OA. AWADAlla, and N.B. EL-BANDY. 1995. Formation of tomatine in tomato plants infected with Streptomyces species and treated with herbicides, correlated with reduction of Pseudomonas solanacearum and Fusarium oxysporum $\mathrm{f}$. $\mathrm{sp}$. lycopersici. Acta Microbiol. Polonica 44: 255-266.

GRINSTEIN, A., N. LISKER, J. KATAN, and Y. ESHEL. 1984. Herbicide-induced resistance to wilt diseases. Physiol. Plant Pathol. 24: 347-356.

HOAGLAND, R.E. 1996. Chemical interactions with bioherbicides to improve efficacy. Weed Technol. 10: 651-674.

HOLLIDAY, M.J. and N.T. KEEN. 1982. The role of phytoalexins in the resistance of soybean leaves to bacteria: effect of glyphosate on glyceollin accumulation. Phytopathology 72: 1470-1474.

JOHAL, G.S. and J.E. RAHE. 1988. Glyphosate, hypersensitivity and phytoalexin accumulation in the incompatible bean anthracnose host-parasite interaction. Physiol. Molec. Plant Pathol. 32: 267-281.

KATAN, J.; ESHEL, Y. 1973. Interactions between herbicides and plant pathogens. Res. Rev. 45: 145-177.

KATARIA, H.R. and U. GISI. 1990. Interactions of fungicide-herbicide combinations against plant pathogens and weeds. Crop Protection 9: 403-409.

KAWATE, S.C., S. KAWATE, A.G. OGG, and J.M. KRAFT. 1992. Response of Fusarium solani f. sp. pisi and Pythium ultimum to glyphosate. Weed Sci. 40:497-502.

KÖMIVES, T. and J.E. CASIDA. 1983. Acifluorfen increases the leaf content of phytoalexins and stress metabolites in several crops. J. Agric. Food Chem. 31: 751-755.

KOVACS, A. and C. MALLIGNI. 1975. Effect of herbicides on diseases of cultivated plants. Notiziario sulle Malattie delle Piante 92-93: 239-252.

LATUNDE-DADA, A.O. and J.A. LUCAS. 1985. Involvement of the phytoalexin medicarpin in the differential response of callus lines of lucerne (Medicago sativa) to infection by Verticillium albo atrum. Physiol. Plant Pathol. 26: 31-42

LEVESQUE, C. ANDRE; RAHE, JAMES E. 1992. Herbicide interactions with fungal root pathogens, with special reference to glyphosate. Ann. Rev. Phytopathol. 30: 579-602.

LIU, C.-AN., H. ZHONG, J. VARGAS, D. PENNER, and M. STICKLEN. 1998. Prevention of fungal diseases in transgenic, bialaphos- and glufosinate-resistant creeping bentgrass (Agrostis palustris). Weed Sci. 46: $139-146$

LIU, L., Z.K. PUNJA, and J.E. RAHE. 1997 Altered root exudation and suppression of induced lignification as mechanisms of predisposition by glyphosate of bean roots (Phaseolus vulgaris L.) to colonization by Pythium spp. Physiol. Mol. Plant Pathol. 51: 111-127.

NEUMANN, G., S. KOHLS, E. LANDSBERG, K. STOCK-OLIVEIRA SOUZA, T. YAMADA, and V. RÖMHELD. 2006. Relevance of glyphosate transfer to non-target plants via the rhizosphere. J. Plant Dis. Protect. Special Issue 20: 963-969. 
PLINE, W.A., G.H. LACY, V. STROMBERG, and K.K. HATZIOS. 2001. Antibacterial activity of the herbicide glufosinate on Pseudomonas syringae Pathovar Glycina. Pestic. Biochem. Physiol. 71: 48-55.

SANOGO, S., X.B. YANG, and P. LUNDEEN. 2001. Field response of glyphosate-tolerant soybean to herbicides and sudden death syndrome. Plant Dis. 85: 773-779.

SHARMA, S.R. and H.S. SOHI. 1983. Influence of herbicides on root rot of French beans (Phaseolus vulgaris L.), caused by Rhizoctonia solani. Zentralbl. Mikrobiol. 138: 357-361.

SHARON, A., Z. AMSELLEM, and J. GRESSEL. 1992. Glyphosate suppression of an elicited response. Increased susceptibility of Cassia obtusifolia to a mycoherbicide. Plant Physiol. 98: 654-659.

TAMOGAMI, S., O. KODAMA, K. HIROSE, and T. AKATSUKA. 1995. Pretilachlor [2-chloro-N-(2, 6diethylphenyl)-N-(2-propoxyethyhl) acetamide]- and butachlor [N-(butoxymethyl)-2-chloro- $\mathrm{N}-(2,6-$ diethlphenyl)acetamide]-induced acumulation of phytoalexin in rice (Oryza sativa) plants. J. Agric. Food Chem. 43: 1695-1697.

TOUBIA-RAHME, H., D.-E. ALI-HAIMOUD, G. BARRETT, and L. ALBERTINI. 1995. Inhibition of Dreschlera teres schleroid formation in barley straw by application of glyphosate or paraquat. Plant Dis. 79: 595-598.

TUBAJIKA, K.M. and K.E. DAMANN. 2002. Glufosiante-ammonium reduces growth and aflatoxin B1 production by Aspergillus flavus. J. Food Prod. 65: 1483-1487.

UCHIMIYA, H., M. IWATA, C. NOJIRI, P.K. SAMARAJEEWA, S. TAKAMATSU, S. OOBA, H. ANZAI, A.H. CHRISTENSEN, P.H. QUAIL, and S. TOKI. 1993. Bialaphos treatment of transgenic rice plants expressing the bar gene prevents infection by the sheath leaf blight pathogen (Rhizoctonia solani). Bio/Biotechnol. 11: 835-836.

WANG, Y., M. BROWNING, B.A. RUEMMELE, A. BRIDGER, J.M. CHANDLEE, A.P. KAUSCH, and N. JACKSON. 2003. Glufosinate reduces fungal diseases in transgenic glufosinate-resistant bentgrasses (Agrostis spp.) Weed Sci. 51: 130-137.

WARD, E.W.B. 1984. Suppression of metalaxyl activity by glyphosate. Evidence that host defence mechanisms contribute to metalaxyl inhibition of Phytopthora megasperma F Sp. glycinea to soybeans. Physiol. Plant Pathol. 25: 381-386.

WYSE, G.S. and H. MULLER-SCHARER. 2001. Effects of selected herbicides on the germination and infection process of Puccinia lagenophora, a biocontrol pathogen of Senecio vulgaris. Biol. Control 20: 160166.

YU, S.-M., G.E. TEMPLETON, and D.C. WOLF. 1988. Trifluralin concentration and the growth of Fusarium solani f. sp. cucurvitae in liquid medium and soil. Soil Biol. Biochem. 20: 607-612. 